\title{
Public Comment on the National Science Foundation's Information Collection Request: 2019 Survey of Doctorate Recipients (FR Doc. 2018-17359)
}

\author{
Jonathan B. Freeman, PhD \\ Associate Professor of Psychology and Neural Science \\ New York University \\ Adam P. Romero, JD \\ Director of Legal Scholarship and Federal Policy \\ UCLA School of Law, Williams Institute \\ Laura Durso, PhD \\ Vice President, LGBT Research and Communications Project \\ Center for American Progress
}

\begin{abstract}
We submit this public comment in response to the National Science Foundation's proposed information collection request related to the 2019 Survey of Doctorate Recipients (SDR), published in the Federal Register at 83 FR 40340 on August 14, 2018. We outline the importance of including sexual orientation and gender identity (SO/GI) demographic measures on the SDR (and related NSF surveys) for advancing the U.S. scientific workforce, and the feasibility and precedent in implementing SO/GI measures in government surveys. The comment is cosigned by 17 scientific organizations and 251 scientists, engineers, and legal and policy scholars.
\end{abstract}

Correspondence to: ion.freeman@nyu.edu

Submitted: October 8, 2018 
October 8, 2018

Ms. Suzanne H. Plimpton

Reports Clearance Officer

National Science Foundation

2415 Eisenhower Ave., Suite W18253

Alexandria, VA 22314

Via regulations.gov and email

RE: National Science Foundation; Intent To Seek Approval To Renew An Information

Collection For Three Years; Notice and request for comments; 2019 Survey of Doctorate

Recipients (Federal Register Doc. 2018-17359)

Dear Ms. Plimpton:

We are grateful for the opportunity to comment on the National Science Foundation's proposed information collection request related to the 2019 Survey of Doctorate Recipients (SDR). See 83 Fed. Reg. 40340 (August 14, 2018). We are a group of 17 scientific organizations and associations of higher education, including the American Association for the Advancement of Science and American Association of University Professors, and 243 scientists and engineers, including 17 members of the National Academies, committed to promoting diversity in science, technology, engineering, and math (STEM) fields and inclusion of under-represented groups in our nation's STEM workforce. We write jointly with 8 scholars at the Williams Institute and other institutions who have long worked with federal agencies to improve data collection on the U.S. population and have produced widely-cited best practices for the collection of sexual orientation and gender identity information on population-based surveys. ${ }^{1}$ The Williams Institute is an interdisciplinary center at the UCLA School of Law dedicated to rigorous and independent research on sexual orientation and gender identity, including on employment and education of lesbian, gay, bisexual, and transgender (LGBT) people.

Our comments address the importance and feasibility of including sexual orientation and gender identity measures on the SDR and related surveys administered by the National Science Foundation's National Center for Science \& Engineering Statistics, including the National Survey of College Graduates (NSCG) and the Survey of Earned Doctorates (SED). Incorporating measures of sexual orientation and gender identity into the SDR, NSCG, and SED would enhance the quality and utility of the information collected, because doing so would provide vital

\footnotetext{
${ }^{1}$ See Sexual Minority Assessment Research Team (SMART), Williams Institute, Best Practices for Asking Questions about Sexual Orientation on Surveys (2009), https://williamsinstitute.law.ucla.edu/wpcontent/uploads/SMART-FINAL-Nov-2009.pdf; Gender Identity in U.S. Surveillance (GenIUSS) Group, Williams Institute, Best Practices for Asking Questions to Identify Transgender and Other Gender Minority Respondents on Population-Based Surveys (2014), https://williamsinstitute.law.ucla.edu/wp-content/uploads/geniuss-report-sep2014.pdf.
} 
data on the participation of LGBT people, also called sexual and gender minorities, in STEM education and their representation in our nation's STEM workforce.

Like race, sex, and other personal demographic data already collected on the SDR, NSCG, and SED ${ }^{2}$ data on the sexual orientation and gender identity of college graduates and doctoral degree holders in STEM fields would enhance the ability of the National Science Foundation, the Census Bureau, the National Science Board, and the surveys' co-sponsoring agencies - the National Institutes of Health, Department of Education, Department of Agriculture, National Endowment of the Humanities, and National Aeronautics and Space Administration - to improve the understanding of the U.S. STEM workforce. Collecting sexual orientation and gender identity information would increase the utility of official reports, including the National Science Board's Science \& Engineering Indicators report and the National Science Foundation's Women, Minorities, and Persons with Disabilities in Science and Engineering report. These reports and data from the SDR, NSCG, and SED more generally are used not only by their sponsoring agencies but also by policymakers, the Office of Management and Budget, the Office of Science and Technology Policy, state and local government agencies, and educational and research institutions across the nation. Adding sexual orientation and gender identity information would further these reports' goals of providing important information on the condition and progress of the nation's STEM fields, including demographic trends, and of understanding and strengthening the participation of under-represented groups in the U.S. STEM workforce and U.S. undergraduate and graduate programs.

\section{Including Sexual Orientation and Gender Identity Measures in the SDR, NSCG, and SED Would Enhance the Quality and Utility of the Information Being Collected}

As in previous versions of the survey, the proposed 2019 SDR would collect some types of personal information from respondents, including race, ethnicity, sex, age, income, and disability status, ${ }^{3}$ which we support. However, while the proposed SDR would collect a variety of personal demographic information from respondents, it would not collect data on respondents' sexual orientation or gender identity. Including measures of sexual orientation and gender identity in the SDR (as well as the NSCG and SED) would enhance the quality and utility of the information being collected.

There has been a growing recognition of the need to measure sexual orientation and gender identity in the STEM workforce. ${ }^{4}$ As summarized last month in the scientific journal Nature, recent studies show that LGBT people are experiencing disadvantages and disparities in STEM fields similar to other under-represented groups, such as racial and ethnic minorities and

\footnotetext{
${ }^{2}$ We note that some demographic information (e.g., race, sex) is not re-collected on the NSCG or SDR if already collected from a given respondent in a previous survey cycle (or, for the SED, if previously collected from the SDR). Throughout our comment, by collection of demographic information we refer to the availability of that information, whether it is collected on a present or previous cycle.

${ }^{3}$ National Science Foundation, National Center for Science and Engineering Statistics, Survey of Doctorate Recipients (2018), https://www.nsf.gov/statistics/srvydoctoratework

${ }^{4}$ Wimberly, G. L. (2015). Conclusion and recommendations for further research. In G.L. Wimberly (Ed.), LGBTQ Issues in Education: Advancing a Research Agenda, pp. 237-251. American Educational Research Association. https://books.google.com/books?hl=en\&lr=\&id=2YElDwAAQBAJ
} 
women. ${ }^{5}$ Estimates suggest that LGBT people are approximately $20 \%$ less represented in STEM fields than expected based on their prevalence in the U.S. population. ${ }^{6}$ A 2018 study found that sexual-minority undergraduates were $8 \%$ more likely than their heterosexual counterparts to drop out of STEM majors, even though they were more likely to pursue relevant research experience a pattern commonly associated with difficulties in retaining women and racial and ethnic minorities in STEM fields due to a non-supportive STEM culture. ${ }^{7}$

Indeed, several studies have shown that LGBT people encounter non-supportive environments in STEM fields. LGBT people report more negative workplace experiences in STEM fields than do non-LGBT people in those same fields, or than do LGBT people in nonSTEM industries. ${ }^{6}$ Among sexual-minority STEM faculty members who are 'out' about their sexual orientation, $69 \%$ report feeling uncomfortable in their academic department, which is related to exclusion and harassment they report. ${ }^{8}$ Some STEM fields, such as chemistry, have conducted surveys on the professional environment that included questions of sexual orientation and gender identity. In a 2016 survey in chemistry, 44\% of LGBT people reported that they were harassed, intimidated, or excluded at work. ${ }^{9}$

As noted by the 2018 National Academies' Measuring the 21st Century Science and Engineering Workforce Population: Evolving Needs report, the science and engineering workforce "is becoming increasingly diverse...in terms of gender, race/ethnicity, and other characteristics". ${ }^{10}$ In this respect, the report highlights an evolving need:

Future recruitment, growth, and development of the nation's scientists and engineers will depend on greater understanding not only of the diverse composition of the science and engineering workforce but also of the factors that facilitate or impede the entry, retention, and advancement of underrepresented groups in the workforce. ${ }^{10}$

Inclusion of sexual orientation and gender identity measures on the SDR, NSCG, and SED would directly address such evolving needs identified by the National Academies. Doing so would provide important data regarding how LGBT people navigate the STEM environment from their undergraduate and graduate education through to the workforce - and where they may experience barriers to entering or remaining in STEM fields. Such data would also provide information about the experiences of LGBT people in STEM more generally, including, for

\footnotetext{
${ }^{5}$ Freeman, J. B. LGBTQ scientists are still left out, 36 Nature, 559, pp. 27-28 (July 3, 2018).

${ }^{6}$ Cech, E. A., and Pham, P.V. Queer in STEM organizations: Workplace disadvantages for LGBT employees in STEM related federal agencies. Social Sciences 6.1 (2017); Cech, Erin A. "LGBT professionals' workplace experiences in STEM-related federal agencies." Proceedings of the 2015 American Society for Engineering Education (ASEE) National Conference, Seattle, WA, USA. 2015., https://peer.asee.org/lgbt-professionalsworkplace-experiences-in-stem-related-federal-agencies

${ }^{7}$ Hughes, B.E., 2018. Coming out in STEM: Factors affecting retention of sexual minority STEM students. Science advances, 4(3), p.eaao6373.

${ }^{8}$ Patridge, E.V., Barthelemy, R.S. and Rankin, S.R., 2014. Factors impacting the academic climate for LGBQ STEM faculty. Journal of Women and Minorities in Science and Engineering, 20(1).

${ }^{9}$ Wang, L (2016) LGBT chemists seek a place at the bench. Chemical Engineering and News, 94:41, 18-20.

${ }^{10}$ National Academies, Measuring the 21st Century Science and Engineering Workforce Population: Evolving Needs (2018), https://www.nap.edu/catalog/24968/measuring-the-21st-century-science-and-engineering-workforcepopulation-evolving
} 
example, whether they are satisfied with their jobs, receiving sufficient professional support, or experiencing pay inequality.

There are many potential uses of sexual orientation and gender identity data in STEM workforce surveys. For example, such data would inform institutions, agencies, and researchers developing strategies to address under-representation or career or educational barriers experienced by LGBT people. Reports based on SDR, NSCG, and SED data, including the Science \& Engineering Indicators and Women, Minorities, and Persons with Disabilities in Science and Engineering reports, are routinely used by policymakers overseeing diversity initiatives at educational and research institutions across the nation and at funding agencies, including the National Science Foundation and National Institutes of Health. Data on LGBT representation could therefore similarly inform such diversity programs, as these programs may be interested to address under-representation of LGBT people in specific STEM fields and career stages, if and where it exists. As with other under-represented groups, such diversity initiatives could include fellowships for doctoral students, scholarships for undergraduate students, or recruitment strategies for faculty, graduate students, and/or postdoctoral researchers. More generally, the data would also inform research aimed at developing interventions or paradigms to reduce disadvantages experienced by LGBT scientists and engineers.

In short, including sexual orientation and gender identity measures in the SDR, NSCG, and SED would increase the quality and utility of the information collected, because such data would enhance the understanding of diverse and under-represented groups' participation in STEM education and their representation in the STEM workforce.

\section{Importance of Governmental Data Collection on Sexual Orientation and Gender Identity (SO/GI); SO/GI Data Collection is Becoming Increasingly Common}

Adding sexual orientation and gender identity measures to the SDR, NSCG, and SED would reflect a growing trend among federal, state, and other data collections that include demographic measures. This trend is responsive to a need succinctly described by the Federal Interagency Working Group on Improving Measurement of Sexual Orientation and Gender Identity in Federal Surveys:

At a time when sexual and gender minority (SGM) populations are becoming more visible in social and political life, there remains a lack of data on the characteristics and well-being of these groups. In order to understand the diverse needs of SGM populations, more representative and better quality data need to be collected. ${ }^{11}$

A growing number of federal government surveys allow people to voluntarily disclose their sexual orientation and/or gender identity. Examples of federal government surveys that collect these data include the National Health Interview Survey, Behavioral Risk Factor

\footnotetext{
${ }^{11}$ Federal Interagency Working Group on Improving Measurement of Sexual Orientation and Gender Identity in Federal Surveys, Current Measures of Sexual Orientation and Gender Identity in Federal Surveys (2016), https://s3.amazonaws.com/sitesusa/wpcontent/uploads/sites/242/2014/04/WorkingGroupPaper1_CurrentMeasures_08-16.pdf.
} 
Surveillance System, Youth Risk Behavior Surveillance System, National Survey for Family Growth, and National Crime Victimization Survey, among others. ${ }^{11}$ Further, several state and local government surveys also collect data on sexual orientation and gender identity, such as the California Health Interview Survey, ${ }^{12}$ as do several large surveys administered by private entities, most notably Gallup through its Daily Tracking Survey. ${ }^{13}$

While more and better data are needed, governmental and other data collections that include measures of sexual orientation and gender identity have allowed researchers to begin to describe the size of the LGBT population and LGBT people's demographics; employment, housing, and family circumstances; health and well-being; and the discrimination and disparities they face. These data are vital to policymaking in order to ensure that stereotypes and myths are not driving policies that impact LGBT people, and so that programs and services are appropriately targeted at vulnerable LGBT populations. For example, we now know that there are an estimated 11 million LGBT individuals living in the U.S. ${ }^{13}$ We also know from the data that the LGBT population is remarkably diverse and that the experiences of LGBT people are not uniform but, rather, are shaped by factors such as race, ethnicity, socioeconomic status, geographical location, primary language, education, disability, religion, family composition, and age. ${ }^{14}$ We have also learned that LGBT people are more likely to be in poverty than non-LGBT people, ${ }^{15}$ contrary to the popular stereotype of LGBT affluence, and that LGBT people face persistent and pervasive discrimination in employment, housing, educational, and other important settings. ${ }^{16}$ Noting the disadvantages LGBT people are facing in STEM fields (see Section I), the inclusion of sexual orientation and gender identity measures in STEM workforce surveys (SDR, NSCG, and SED) would provide similarly vital information about the experiences, career trajectory, and representation of LGBT people in STEM fields.

\section{Experience Indicates SDR, NSCG, and SED Respondents Would Willingly and Accurately Disclose Their Sexual Orientation And Gender Identity}

Federal and other population-based surveys that collect sexual orientation and gender identity data indicate SDR, NSCG, and SED respondents would be willing and are able to answer questions about their sexual orientation and gender identity, and doing so would not raise privacy or other concerns. As an initial matter, we note that the National Science Foundation's National Center for Science \& Engineering Statistics and the Census Bureau (who directly administers the NSCG) remove respondents' names and other identifying information, in

\footnotetext{
${ }^{12}$ National Cancer Institute, Division of Cancer Control and Population Sciences, National Health Interview Survey (2018), https://healthcaredelivery.cancer.gov/chis

${ }^{13}$ Gallup, In U.S., Estimate of LGBT Population Rises to 4.5\% (2018), https://news.gallup.com/poll/234863/estimate-lgbt-population-rises.aspx

${ }^{14}$ Institute of Medicine, The Health of Lesbian, Gay, Bisexual, and Transgender People: Building a Foundation for Better Understanding (2011), http://www.iom.edu/Reports/2011/The-Health-of-Lesbian-Gay-Bisexual-andTransgender-People.aspx.

${ }^{15}$ Badgett et al., Williams Institute, New Patterns of Poverty in the Lesbian, Gay, and Bisexual Community (2013), http://williamsinstitute.law.ucla.edu/wp-content/uploads/LGB-Poverty-Update-Jun-2013.pdf.

${ }^{16}$ See, e.g., Pizer et al., Evidence of Persistent and Pervasive Workplace Discrimination Against LGBT People, 45 Loy. L.A. L. Rev 715 (2012); James et al., Nat'l Ctr. for Transgender Equality, Report of the 2015 U.S. Transgender Survey 44-45 (2016), http://www.transequality.org/sites/default/files/docs/usts/USTS\%20Full\%20Report\%20\%20FINAL\%201.6.17.pdf.
} 
addition to other measures, to protect respondents' confidentiality. And federal law protects the confidentiality of individually identifiable information collected by these agencies. ${ }^{17}$

Experience shows that respondents are willing to answer questions about their LGBT status. Indeed, the Federal Interagency Working Group on Improving Measurement of Sexual Orientation and Gender Identity in Federal Surveys has explained that "[m]ost surveys incorporating [sexual orientation and gender identity] items have not found higher nonresponse rates than other 'sensitive' questions, such as personal or household income." ${ }^{18}$ Likewise, federal surveys incorporating these measures and other research demonstrate that including sexual orientation and gender identity questions does not cause survey breakoff. ${ }^{19}$

Although nearly all college graduates and doctoral degree holders taking the SDR, NSCG, and SED are adults, the sample includes those who would be considered young adults. Experiences with other federal government and population-based surveys show that youth and young adults are capable and willing to answer questions about sexual orientation and gender identity. For example, as the Sexual Minority Assessment Research Team report explained, "[s]exual orientation questions have been asked on large-scale school-based surveys of adolescents around the world since the mid-1980's."1 For instance, the National Survey of Youth in Custody includes a measure of sexual orientation, ${ }^{20}$ and the National Youth Risk Behavior Survey successfully includes respondents as young as 13 and has included sexual orientation measures since 2015. The National Survey of Family Growth, which includes respondents as young as 15 , has included a sexual orientation behavior measure for many years. ${ }^{21}$

While sexual orientation and gender identity data should be treated with the same concern for confidentiality of respondents as any other demographic category, there is no rational basis to single out the questions on sexual orientation and gender identity as warranting special concern about the sensitivity of this type of information. As noted above, sexual orientation and gender identity measures do not have materially higher non-response rates than other potentially

${ }^{17}$ U.S. Census Bureau, National Survey of College Graduates, Frequently Asked Questions (2018), https://www.census.gov/programs-surveys/nscg/respondent/faqs.html

${ }^{18}$ Federal Interagency Working Group on Improving Measurement of Sexual Orientation and Gender Identity in Federal Surveys, Current Measures of Sexual Orientation and Gender Identity in Federal Surveys (2016), https://s3.amazonaws.com/sitesusa/wpcontent/uploads/sites/242/2014/04/WorkingGroupPaper1_CurrentMeasures_08-16.pdf; see also Saewyc, E.M. et al., Measuring sexual orientation in adolescent health surveys: Evaluation of eight school-based surveys, $35 \mathrm{~J}$. of Adolescent Health 345 (2004) ("These studies indicate that orientation items, although sensitive questions, are no more sensitive or more likely to be skipped than other sexual risk behavior questions. This finding can reassure researchers and school administrators who are concerned that such items might be too sensitive for most students to answer, and who worry that nonresponse rates will render the results inaccurate and of limited use.").

${ }^{19}$ See, e.g., Landers et al., Presentation: Developing Data for Advocacy (National LGBTI Health Summit: 2007); Case, Disclosure of Sexual Orientation and Behavior in the Nurses' Health Study II: Results from a Pilot Study, 51 J. Homosexuality 13 (2006).

${ }^{20}$ Bureau of Justice Statistics, Data Collection: National Survey of Youth In Custody (NSYC), https://www.bjs.gov/index.cfm?ty=dcdetail\&iid=321 (last visited May 5, 2018); Bureau of Justice Statistics, NYSC Questionnaire - Younger Youth 5 (2011) https://www.bjs.gov/content/pub/pdf/nsyc yy12.pdf; Bureau of Justice Statistics, NYSC Questionnaire—Older Youth, 5 (2011), https://www.bjs.gov/content/pub/pdf/nsyc oy12.pdf.

${ }^{21}$ See Anjani Chandra et al., Sexual Behavior, Sexual Attraction, and Sexual Identity in the United States: Data From the 2006-2008 National Survey of Family Growth, 36 National Health Statistics Reports 1 (Mar. 3, 2011), https://www.cdc.gov/nchs/data/nhsr/nhsr036.pdf. 
sensitive personal questions. Moreover, according to the Federal Interagency Working Group, "[the] perceived sensitivity of questions can affect the willingness of survey practitioners to include [sexual orientation and gender identity] questions even when inclusion of these measures would support agency mission and data needs." ${ }^{22}$ In this case, the inclusion of these measures strongly supports the mission of the National Science Foundation and furthers the goals of several federal agencies, as described in Section I.

We recognize that sexual orientation and gender identity questions could be sensitive for certain respondents, although there is no reason to believe they would be more sensitive than other questions, such as income or disability status. And even if the sexual orientation and gender identity questions would be sensitive for some respondents, the questions would be voluntary, as is the case in other federal government surveys and recommended by the Federal Interagency Working Group. Thus, no respondent would be forced to answer these questions. In other federal government surveys, these questions frequently have "don't know" and "something else" or "none of these" response options, giving respondents options for responding to these questions if they are uncomfortable disclosing or unsure about their sexual orientation or gender identity. ${ }^{1}$ In addition, as described earlier, responses are highly confidential and are strongly protected under federal law.

In short, previous experiences in governmental and other data collection suggest that SDR, NSCG, and SED respondents will not encounter any issues in willingly and accurately disclosing information about sexual orientation and gender identity. Nor will such disclosures introduce issues of confidentiality or privacy, a high non-response rate, or survey breakoff.

\section{The SDR, NSCG, and SED Have Sufficiently Large Samples to Produce Reliable Estimates Related to Sexual Orientation And Gender Identity}

The Federal Interagency Working Group on Improving Measurement of Sexual Orientation and Gender Identity in Federal Surveys cautions that small samples may lead to significant errors in estimation and description and/or an inability to produce reliable estimates related to sexual orientation and gender identity. ${ }^{22}$ However, the current sample sizes of the SDR, NSCG, and SED are all sufficiently large, and thus there is no rational basis for concerns related to small sample sizes in the context of these STEM workforce surveys.

For instance, recent versions of other federal government surveys, such as the National Health Interview Survey and National Survey of Family Growth, entailed sample sizes of approximately $87,500{ }^{23}$ and $10,000,{ }^{24}$ respectively, and both surveys currently collect information about sexual orientation. Sample sizes of the SDR, NSCG, and SED are far larger:

\footnotetext{
${ }^{22}$ Federal Interagency Working Group on Improving Measurement of Sexual Orientation and Gender Identity in Federal Surveys, Evaluations of Sexual Orientation and Gender Identity Survey Measures: What Have We Learned? (2016), https://s3.amazonaws.com/sitesusa/wpcontent/uploads/sites/242/2014/04/Evaluations of_SOGI_Questions_20160923.pdf.

${ }^{23}$ Center for Disease Control and Prevention, National Health Interview Survey (2018), https://www.cdc.gov/nchs/nhis/about_nhis.htm

${ }^{24}$ Center for Disease Control and Prevention, National Survey of Family Growth (2018)

https://www.cdc.gov/nchs/nsfg/about_nsfg.htm
} 
the NSCG has a sample of approximately 135,000, the SDR approximately 120,000, and the SED approximately 55,000. ${ }^{10}$ Thus, concerns of small sample size are unwarranted.

The SDR, NSCG, and SED routinely ask about race and ethnicity information, and many of the race and ethnicity classifications have a prevalence in the U.S. population that is smaller than that of LGBT people. For instance, the 2017 Women, Minorities, and People with Disabilities in Science and Engineering report provides recent estimates of each race and ethnicity classification's prevalence in the U.S. population, so as to permit comparison with corresponding percentages in science and engineering fields. For the following four race and ethnicity classifications included in the 2017 report (and collected in the SDR, NSCG, and SED), their prevalence estimate in the U.S. population is:

- Asian: $5.3 \%$

- American Indian or Alaska Native: $0.7 \%$

- Native Hawaiian or other Pacific Islander: 0.2\%

- Two or more races (not Hispanic): $2.0 \%{ }^{25}$

Despite being quite small, STEM workforce surveys currently provide full data on each of these race and ethnicity classifications. Most recent estimates of the prevalence of LGBT people in the U.S. adult population, according to the Gallup's 2017 Daily Tracking Survey $(n=340,604)$, is $4.5 \% .{ }^{13}$ This prevalence is roughly on par or only slightly smaller than that of the U.S. Asian population, and is considerably higher than those of the other three race and ethnicity classifications. Thus, the SDR, NSCG, and SED currently collect information on race and ethnicity classifications that have expected samples smaller than those of LGBT people.

Finally, reports of SDR, NSCG, and SED data, such as the Women, Minorities, and People with Disabilities in Science and Engineering report, typically suppress a cell of data only if the sample constituting that data cell is less than $0.1 \%$ (due to concerns of an unreliable estimate or that so few respondents raises concerns of identifiability), and this is far lower than 4.5\%. Dividing into specific subgroups and intersections with other demographic information in theory could lead to subgroup samples constituting less than $0.1 \%$ or where concerns of unreliability of identifiability are relevant. However, as with the race and ethnicity classifications currently collected with even smaller samples, such specific LGBT subgroup data could be suppressed wherever necessary. That certain subgroups or intersections may have overly small sample sizes does not warrant the wholesale exclusion of sexual orientation and gender identity information more generally.

Given that federal surveys with smaller sample sizes than the SDR, NSCG, and SED already currently collect sexual orientation and gender identity information, and that these STEM workforce surveys routinely collect information related to race and ethnicity classifications that have smaller prevalence in the U.S. population than LGBT people, concerns of unreliable or invalid estimates of LGBT people in STEM workforce surveys have no substantive support.

\footnotetext{
${ }^{25}$ National Science Foundation, National Center for Science \& Engineering Statistics, 2017 Women, Minorities, and Persons with Disabilities in Science and Engineering Report https://www.nsf.gov/statistics/2017/nsf17310/data.cfm
} 


\section{Conclusion}

The National Science Foundation is committed to promoting diversity in STEM fields and providing resources to ensure that science and engineering are inclusive to all. ${ }^{26}$ Collecting sexual orientation and gender identity data on the SDR, NSCG, and SED would provide vital information about LGBT participation in the STEM pipeline - from undergraduate and graduate education through to the workforce - and LGBT representation among our nation's scientists and engineers. This information would enhance the ability of the National Science Foundation and other federal agencies to provide critical data and support to the scientific community and to advance the future of the U.S. STEM workforce.

Thank you for your consideration. We look forward to opportunities to discuss with you further. Please direct any correspondence to jon.freeman@nyu.edu.

Respectfully Submitted,

Jonathan B. Freeman, PhD

Associate Professor of Psychology and Neural Science

New York University

Adam P. Romero, JD

Arnold D. Kassoy Scholar of Law

Director of Legal Scholarship and Federal Policy

Williams Institute, UCLA School of Law

Laura Durso, $\mathrm{PhD}$

Vice President, LGBT Research and Communications

Center for American Progress

\section{Institutional Signatories:}

American Association for the Advancement of Science (AAAS)

American Association of University Professors (AAUP)

American Anthropological Association (AAA)

American Educational Research Association (AERA)

American Psychological Association (APA)

Association of Population Centers (APC)

${ }^{26}$ National Science Foundation, Office of the Director, Broadening Participation (2018), https://www.nsf.gov/od/broadeningparticipation/bp.jsp 
American Society for Engineering Education (ASEE)

Consortium of Social Science Associations (COSSA)

Federation of Associations in Behavioral and Brain Sciences (FABBS)

Inter-university Consortium for Political and Social Research (ICPSR)

Linguistic Society of America (LSA)

National Organization of Gay and Lesbian Scientists and Technical Professionals (NOGLSTP)

Out in Science, Technology, Engineering, and Mathematics (oSTEM)

Population Association of America (PAA)

Society for Experimental Social Psychology (SESP)

Society for Personality and Social Psychology (SPSP)

Society for Research in Child Development (SRCD)

Individual Signatories (members of the National Academies listed first):

Natalie G. Ahn, PhD

Member, National Academy of Sciences

Professor of Chemistry and Biochemistry

University of Colorado at Boulder

Mahzarin R. Banaji, PhD

Member, National Academy of Sciences

Richard Clarke Professor of Social Ethics

Harvard University

Carolyn R. Bertozzi, PhD

Member, National Academy of Sciences

Anne T. and Robert M. Bass Professor of Chemistry

Stanford University

Axel Brunger, PhD

Member, National Academy of Sciences

Professor of Molecular and Cellular Physiology

Stanford University 
Lynn Ann Conway, PhD

Member, National Academy of Engineering

Professor of Electrical Engineering and Computer Science, Emerita

University of Michigan, Ann Arbor

Ronald S. Duman, PhD

Member, National Academy of Medicine

Elizabeth Mears and House Jameson Professor of Psychiatry, Professor of Neuroscience

Yale School of Medicine

Susan T. Fiske, $\mathrm{PhD}$

Member, National Academy of Sciences

Eugene Higgins Professor of Psychology and Public Affairs

Princeton University

Susan A. Gelman, PhD

Member, National Academy of Sciences

Heinz Werner Distinguished University Professor

University of Michigan

Richard L. Huganir, PhD

Member, National Academy of Sciences

Bloomberg Distinguished Professor

Johns Hopkins University School of Medicine

Raymond Jeanloz, PhD

Member, National Academy of Sciences

Professor of Earth \& Planetary Sciences and Astronomy

University of California, Berkeley

Jay D. Keasling, PhD

Member, National Academy of Engineering

Professor of Chemical \& Biomolecular Engineering and Bioengineering

University of California, Berkeley

John H. Krystal, MD

Member, National Academy of Medicine

Robert L. McNeil, Jr. Professor of Translational Research, Professor of Psychiatry

Yale School of Medicine

Robert C. Malenka, MD, PhD

Member, National Academy of Sciences

Member, National Academy of Engineering

Member, National Academy of Medicine

Nancy Friend Pritzker Professor in Psychiatry and Behavioral Sciences

Stanford University 
Eric J. Nestler, MD, PhD

Member, National Academy of Medicine

Nash Family Professor of Neuroscience

Icahn School of Medicine at Mount Sinai

James T. Randerson, $\mathrm{PhD}$

Member, National Academy of Sciences

Ralph J. and Carol M. Cicerone Professor of Earth System Science

University of California, Irvine

Henry L. Roediger, III, PhD

Member, National Academy of Sciences

James S. McDonnell Distinguished University Professor

Washington University in St. Louis

Elizabeth S. Spelke, PhD

Member, National Academy of Sciences

Marshall L. Berkman Professor of Psychology

Harvard University

Christian N. Adames, AB

Graduate Student

Teachers College, Columbia University

Alex Aslam Ahmed

Doctoral Student

Northeastern University

David M. Amodio, PhD

Associate Professor of Psychology

New York University

Derek Applewhite, $\mathrm{PhD}$

Assistant Professor of Biology

Reed College

Joshua Aronson, $\mathrm{PhD}$

Associate Professor of Applied Psychology

New York University

Emily Balcetis, $\mathrm{PhD}$

Associate Professor of Psychology

New York University 
Lisa Feldman Barrett, PhD

University Distinguished Professor of Psychology

Northeastern University

Laura Baumgartner, $\mathrm{PhD}$

Instructor of Biology

Front Range Community College

Jay Van Bavel, $\mathrm{PhD}$

Associate Professor of Psychology

New York University

Mark Baxter, PhD

Professor of Neuroscience

Icahn School of Medicine at Mount Sinai

Lauren B. Beach, JD/PhD

Postdoctoral Reseach Fellow

Northwestern University

Elliot Berkman, $\mathrm{PhD}$

Associate Professor of Psychology

University of Oregon

Rick A. Bevins, PhD

Chair and Professor of Psychology

University of Nebraska - Lincoln

Benjamin de Bivort, $\mathrm{PhD}$

Thomas D. Cabot Associate Professor of Organismic and Evolutionary Biology

Harvard University

Bronwyn H. Bleakley, PhD

Associate Professor of Biology

Stonehill College

Walter Bockting, $\mathrm{PhD}$

Professor of Medical Psychology (in Psychiatry and Nursing)

Columbia University

Adair Borges, BS

Graduate Student

University of California, San Francisco 
Nathaniel Braffman

$\mathrm{PhD}$ Candidate

Harvard University

Natalie Brito, PhD

Assistant Professor

New York University

Jeff Brooks

$\mathrm{PhD}$ Student

New York University

Catherine Brown, MA

Graduate Student

University of Nebraska-Lincoln

Christina M. Brown, PhD

Associate Professor of Psychology

Arcadia University

William R Buchanan, $\mathrm{PhD}$

Executive Director

Performing Arts \& Creative Education Solutions Consulting

Tyler Burleigh, PhD

Research Scientist

Data Cubed LLC

Carlos Cardenas-Iniguez, MA

Graduate Student, Psychology

University of Chicago

Anna Carter, $\mathrm{PhD}$

Postdoctoral Research Associate

Iowa State University

Stephen J. Ceci, PhD

Helen L. Carr Professor of Developmental Psychology

Cornell University

Pauline Charbogne, $\mathrm{PhD}$

Postdoctoral fellow

Johns Hopkins University 
Robert S. Chavez, PhD

Assistant Professor of Psychology

University of Oregon

Jacqueline M. Chen, $\mathrm{PhD}$

Assistant Professor of Psychology

University of Utah

Nicholas D. Chiappini, BA

Graduate Student

Stanford University

Jason C. Chow, PhD

Assistant Professor of Special Education

Virginia Commonwealth University

Joseph Cimpian, $\mathrm{PhD}$

Associate Professor of Economics and Education Policy

Chair, Scholars and Advocates for Gender Equity in Education Research (AERA)

New York University

Andrei Cimpian, PhD

Associate Professor of Psychology

New York University

Jasmin Cloutier, $\mathrm{PhD}$

Assistant Professor of Psychological \& Brain Sciences

University of Delaware

Kim Cobb, PhD

Georgia Power Chair and ADVANCE Professor

Professor of Earth and Atmospheric Sciences

Georgia Tech

Shana Cole, $\mathrm{PhD}$

Assistant Professor of Psychology

Rutgers University

Anthony G. Collins

University President

Clarkson University

Kent Connell, BS

PhD Candidate in Ecology

Kansas State University 
Matthew Davis, MSc

$\mathrm{PhD}$ Candidate

University of New South Wales

Sarah DeArmond, PhD

Associate Professor of Management \& Human Resources, Department Chair

University of Wisconsin Oshkosh

Jasmine DeJesus, $\mathrm{PhD}$

Assistant Professor of Psychology

University of North Carolina at Greensboro

Amanda B. Diekman, PhD

Professor of Psychological \& Brain Sciences

Indiana University

Roland Dunbrack, PhD

Professor of Biochemistry and Molecular Biophysics

Fox Chase Cancer Center

James Dunlea, BS, MS

Graduate Student

Columbia University

Fred Duong, MA

Graduate Student

Northeastern University

Juan F. Duque, PhD

Assistant Professor of Psychology

Arcadia University

Alice H. Eagly, PhD

Professor of Psychology

Northwestern University

Neville Eclov, PhD

Radiation Therapy Physics Resident

Duke University

Roberto Efrain-Diaz

Graduate Student

University of California, San Francisco 
Anke A. Ehrhardt, PhD

Professor of Medical Psychology (in Psychiatry)

Columbia University

Tanya Marie Evans, PhD

Assistant Professor of Education

University of Virginia

Dominic Fareri, PhD

Assistant Professor of Psychology

Adelphi University

Brian Feinstein, PhD

Research Assistant Professor

Northwestern University

Melissa Ferguson, $\mathrm{PhD}$

Professor of Psychology

Cornell University

Timothy Fessenden, $\mathrm{PhD}$

Postdoctoral Fellow

Massachusetts Institute of Technology

Kara Finnigan, $\mathrm{PhD}$

Professor of Educational Leadership

University of Rochester

Sarah Fischer, MA

Graduate Student

University of Nebraska-Lincoln

Andrew R. Flores, PhD

Assistant Professor of Political Science, Mills College

Visiting Scholar

Williams Institute, UCLA School of Law

Stephen J. Flusberg, PhD

Associate Professor of Psychology

Purchase College, SUNY

Heather Forsythe

Graduate Student

Oregon State University 
Emily Foster-Hanson

$\mathrm{PhD}$ Student

New York University

Annie Hill

PhD Student

New York University

Kathryn Fox, MA

PhD Student

Harvard University

Kurt Fraser, BS, MA

Graduate Student

Johns Hopkins University

Paolo Gabrielli, PhD

Research Scientist

The Ohio State University

Sarah Gaither, PhD

Assistant Professor of Psychology

Duke University

Alexia Galati, $\mathrm{PhD}$

Assistant Professor of Psychological Science

University of North Carolina at Charlotte

Siddharth Garg, PhD

Assistant Professor of Electrical and Computer Engineering

New York University

Nanette Gartrell, MD

Visiting Distinguished Scholar

Williams Institute, UCLA School of Law

Jason C. Garvey, $\mathrm{PhD}$

Assistant Professor of Higher Education and Student Affairs

University of Vermont

Dylan Gee, PhD

Assistant Professor of Psychology

Yale University 
Jennifer Glass, PhD

Assistant Professor of Earth \& Atmospheric Sciences

Georgia Institute of Technology

Miriam B Goodman, $\mathrm{PhD}$

Professor of Molecular \& Cellular Physiology

Stanford University

Adam D. Gracz, PhD

Assistant Professor of Genetics

University of North Carolina at Chapel Hill

Deanna J. Greene, $\mathrm{PhD}$

Assistant Professor of Psychiatry

Washington University School of Medicine

Oliver Grundmann, PhD

Clinical Associate Professor of Medicinal Chemistry

University of Florida

Joshua A Haby, MA, MLS

Graduate Student

University of Nebraska-Lincoln

Kathryn Hamilton, $\mathrm{PhD}$

Assistant Professor of Pediatrics

Children's Hospital of Philadelphia

Nicholas R Harp, BA

Graduate Student in Psychology

University of Nebraska-Lincoln

Michelle Harran, BS

Graduate Student

Johns Hopkins University

Eric Hehman, PhD

Assistant Professor of Psychology

McGill University

Jody L. Herman, PhD

Scholar of Public Policy

Williams Institute, UCLA School of Law 
Melissa Herman, PhD

Assistant Professor of Pharmacology

University of North Carolina, Chapel Hill

Joscelin Rocha Hidalgo

PhD Student

Georgetown University

Mary Himmelstein, $\mathrm{PhD}$

Postdoctoral Fellow

University of Connecticut

Jennifer S. Hirsch, $\mathrm{PhD}$

Professor of Sociomedical Sciences

Columbia University, Mailman School of Public Health

Mark Hoffarth, PhD

Postdoctoral Fellow

New York University

Mirya R. Holman, PhD

Associate Professor of Political Science

Tulane University

Olivia L. Holmes, PhD

Assistant Professor of Psychology

Tennessee State University

Charles Phillip Holmes II, BS

PhD Student, Oceanography

Texas A\&M University

Nicole Horenstein, $\mathrm{PhD}$

Associate Professor of Chemistry

University of Florida

Tonda L. Hughes, PhD, RN, FAAN

Henrik H. Bendixin Professor of International Nursing, Professor of Nursing (in Psychiatry) Columbia University Medical Center

Allison Hung

Undergraduate

Columbia University 
Jeffrey M. Hunger, $\mathrm{PhD}$

Postdoctoral Fellow

University of California, Los Angeles

Ian Hussey

Postdoctoral Fellow

Ghent University, Belgium

Scott Imberman, $\mathrm{PhD}$

Professor of Economics and Education Policy

Michigan State University

Tiffany Ito, PhD

Professor of Psychology and Neuroscience

University of Colorado Boulder

Anne Jefferson, $\mathrm{PhD}$

Associate Professor of Geology

Kent State University

J. David Jentsch, PhD

Empire Innovation Professor of Psychology

Binghamton University

Kerri Johnson, $\mathrm{PhD}$

Professor of Psychology

University of California, Los Angeles

Camille Johnson, $\mathrm{PhD}$

Acting Director, School of Management

San Jose State University

Kenneth Joseph, PhD

Assistant Professor of Computer Science and Engineering

SUNY Buffalo

John T Jost, PhD

Professor of Psychology and Politics

New York University

Sophie Jurgensen, BS, BA

Graduate Student, NSF GRF Fellow

Louisiana State University 
Mike Kaiser, $\mathrm{PhD}$

Instrument Manager

California State University at Northridge

Shamus Khan, PhD

Professor of Sociology, Department Chair

Columbia University

Laura A. King, PhD

Curators' Distinguished Professor

University of Missouri Columbia

Olivia Kirtley, $\mathrm{PhD}$

Postdoctoral Fellow

KU Leuven

Mark Krzmarzick, PhD

Assistant Professor of Civil and Environmental Engineering

Oklahoma State University

Candace Lapan, $\mathrm{PhD}$

Assistant Professor of Psychology

Wingate University

Gina Lee-Glauser, $\mathrm{PhD}$

Vice President for Research \& Scholarship

Clarkson University

Nikki Legate, $\mathrm{PhD}$

Assistant Professor of Psychology

Illinois Institute of technology

Cynthia Levine, $\mathrm{PhD}$

Postdoctoral Fellow

Northwestern University

Neil Lewis, Jr., PhD

Assistant Professor of Communication and Social Behavior

Cornell University

Julie Libarkin, $\mathrm{PhD}$

Professor of Earth and Environmental Sciences

Michigan State University 
Phui Cheng Lim, PhD

Postdoctoral Fellow

University of Nebraska-Lincoln

Corinna Loeckenhoff, PhD

Associate Professor of Human Development

Cornell University

Jason Londo, $\mathrm{PhD}$

Adjunct Associate Professor of Integrative Plant Science USDA/Cornell

Gustav Lundberg

$\mathrm{PhD}$ Student

New York University

Debbie S. Ma, PhD

Associate Professor of Psychology

California State University Northridge

Christy Mallory, JD

Director of State and Local Policy

Williams Institute, UCLA School of Law

Tara M. Mandalaywala, $\mathrm{PhD}$

Assistant Professor of Psychological and Brain Sciences

University of Massachusetts Amherst

Freddie Marquez, BS

Graduate Student

University of California, Irvine

Joshua Martin, $\mathrm{PhD}$

Assistant Professor of Biology

Colby College

Sara E. Mason, $\mathrm{PhD}$

Associate Professor of Chemistry

University of Iowa

Allison Master, $\mathrm{PhD}$

Research Scientist, Institute for Learning \& Brain Sciences

University of Washington 
Elisabetta Matsumoto, $\mathrm{PhD}$

Assistant Professor of Physics

Georgia Tech

Justin L. Matthews, PhD

Assistant Professor of Psychology

California State University, Monterey Bay

Iris Mauss, $\mathrm{PhD}$

Associate Professor of Psychology

UC Berkeley

Gary McDowell, PhD

Executive Director

Future of Research

Matthew McGill, PhD

Research Scientist

Goddard Space Flight Center

Patrick McGonigal, BA

Graduate Student in Clinical Psychology

University of Nebraska Lincoln

Matthias Mehl, $\mathrm{PhD}$

Professor of Psychology

University of Arizona

Pranjal Mehta, $\mathrm{PhD}$

Senior Lecturer of Experimental Psychology

University College London

Peter Mende-Siedlecki, PhD

Assistant Professor of Psychology

University of Delaware

Ilan $\mathrm{H}$. Meyer, $\mathrm{PhD}$

Williams Distinguished Senior Scholar of Public Policy

Williams Institute, UCLA School of Law

Seth J. Meyer, LMSW, PhD

Assistant Professor of Political Science

Bridgewater State University 
Paul Meyer, PhD

Associate Professor of Psychology

University at Buffalo

Heino F. L. Meyer-Bahlburg, PhD

Professor of Clinical Psychology (in Psychiatry)

Vagelos College of Physicians \& Surgeons of Columbia University

Nicholas M Michalak, MS

PhD Candidate

University of Michigan

Kalina Michalska, $\mathrm{PhD}$

Assistant Professor of Psychology

University of California, Riverside

Alyssa Mikytuck, MPP

Graduate Student

Georgetown University

David I. Miller, $\mathrm{PhD}$

Researcher

American Institutes for Research

Daniel Lee Millimet, $\mathrm{PhD}$

Professor of Economics

Southern Methodist University

Tessa Montague, $\mathrm{PhD}$

Postdoctoral Fellow

Harvard University

Jin Montclare, $\mathrm{PhD}$

Professor of Chemical and Biomolecular Engineering

New York University

Katherine Moore, $\mathrm{PhD}$

Assistant Professor of Psychology

Arcadia University

Ethan Morgan, $\mathrm{PhD}$

Postdoctoral Fellow

Northwestern University 
David Moskowitz, PhD

Research Assistant Professor

Northwestern University

Corinne Alison Moss-Racusin, $\mathrm{PhD}$

Assistant Professor of Psychology

Skidmore College

Mary C. Murphy, PhD

Associate Professor and Associate Vice Provost for Student Diversity and Inclusion Indiana University

Maital Neta, PhD

Assistant Professor of Psychology

University of Nebraska-Lincoln

John M. Nicoludis, PhD

Postdoctoral Fellow

University of California, San Francisco

Julie K Norem, $\mathrm{PhD}$

Hamm Professor of Psychology

Wellesley College

Danielle Findley-Van Nostrand, PhD

Assistant Professor of Psychology

Roanoke College

James S. Nowick, PhD

Professor of Chemistry

University of California, Irvine

Tehila Nugiel, MS

Graduate Student

The University of Texas at Austin

Philip Nussenzweig

MD/PhD Student, Clinical Fellow

The Rockefeller University

Jessica O'Brien

Undergraduate

New York University 
Paul A. O'Keefe, PhD

Assistant Professor of Psychology

Yale-NUS College

Allison P. O'Leary, PhD

Assistant Professor of Psychology

Brevard College

DongWon Oh, PhD

Postdoctoral Researcher

New York University

Kristina Olson, $\mathrm{PhD}$

Associate Professor of Psychology

University of Washington

Christina Padilla, MPP

PhD Student

Georgetown University

Elizabeth Levy Paluck, PhD

Professor of Psychology and Public Affairs

Princeton University

Dr. Shauna M Paradine, PhD

Assistant Professor of Chemistry

University of Rochester

Dipanwita Pati, PhD

Postdoctoral Fellow

UNC-Chapel Hill

Karl J. Petersen, PhD

Researcher

Curie Institute

Rachel Pizzie, PhD

Postdoctoral Fellow

Georgetown University

Nick D. Pokorzynski, BSc

Graduate Student

Washington State University 
Morgan Polikoff, PhD

Associate Professor of Education

University of Southern California

Marisa Putnam, MPP

Graduate Student

Georgetown University

Kimberly Quinn, PhD

Associate Professor of Psychology

DePaul University

Kristina Rapuano, $\mathrm{PhD}$

Postdoctoral Fellow

Yale University

Diego Reinero

PhD Student

New York University

Thomas Remble, MS, MPH, DHS

Director of Research, IMPACT

Northwestern University

Kelly Rentscher, $\mathrm{PhD}$

Postdoctoral Scholar

University of California, Los Angeles

Shawn Rhoads, BA.

$\mathrm{PhD}$ student

Georgetown University

Abigail Riemer, MA

Doctoral Student, NSF Fellow

University of Nebraska-Lincoln

Charles Samuel Henry Robinson, BS, MSc

$\mathrm{PhD}$ Candidate

The University of New Mexico

Troy A. Roepke, $\mathrm{PhD}$

Associate Professor of Animal Sciences

Rutgers University 
Fred Rubino

Graduate Student

Harvard University

Stephen T. Russell, PhD

Priscilla Pond Flawn Regents Professor in Child Development

Chair, Department of Human Development and Family Sciences

University of Texas at Austin

Jocelyn Samuels, JD

Executive Director and Roberta A. Conroy Scholar of Law

Williams Institute, UCLA School of Law

Eric J. Schelter, PhD

Professor of Chemistry

University of Pennsylvania

Eric W. Schrimshaw, $\mathrm{PhD}$

Associate Professor of Sociomedical Sciences

Columbia University

Gabriel Schwartz

PhD Candidate

Harvard University

John Sciarappo

Graduate Student

New York University

Heather Sheridan, $\mathrm{PhD}$

Assistant Professor of Psychology

University at Albany, State University of New York

Jeffrey Sherman, PhD

Professor of Psychology

UC Davis

Margaret Shih, PhD

Professor of Psychology

University of California, Los Angeles

Wolfgang Sigmund, PhD

Professor of Materials Science and Engineering

University of Florida 
Jennifer Silvers, $\mathrm{PhD}$

Assistant Professor of Psychology

University of California, Los Angeles

Gale M. Sinatra, PhD

Stephen Crocker Professor of Education

University of Southern California

Christofer Skurka, MS

$\mathrm{PhD}$ Candidate in Communication

Cornell University

Pamela K. Smith, PhD

Associate Professor of Economics and Strategic Management

University of California, San Diego

Jeanine Stefanucci

Associate Professor of Psychology

University of Utah

Janet D. Stemwedel, PhD

Professor of Philosophy

San Jose State University

Ben Stillerman

PhD Student

New York University

Ryan Stolier

$\mathrm{PhD}$ Student

New York University

Steven J. Stroessner, $\mathrm{PhD}$

Professor of Psychology

Barnard College

Daphna Stroumsa, MD, MPH

Clinical Lecturer in Obstetrics \& Gynecology

University of Michigan

Brittany Lynne Sutherland, PhD

Postdoctoral Fellow

University of Arizona 
Abigail L. S. Swann, PhD

Associate Professor of Atmospheric Science and Biology

University of Washington

Elise Swanson

Graduate Student

University of Arkansas

Courtney Sobers Swindell, PhD

Assistant Teaching Professor

Rutgers University-Newark

Rae Thomas, MA

Behavioral Health Counselor - ERC

University of Nebraska - Lincoln

Amy O. Tsui, PhD

Professor of Population, Family and Reproductive Health

Johns Hopkins Bloomberg School of Public Health

Lucina Uddin, $\mathrm{PhD}$

Associate Professor of Psychology

University of Miami

James S. Uleman, $\mathrm{PhD}$

Professor of Psychology

New York University

Fernanda Vasconcelos, $\mathrm{PhD}$

Postdoctoral Fellow

University of Florida

Bess Vlaisavljevich, $\mathrm{PhD}$

Assistant Professor of Chemistry

University of South Dakota

Austin Wadle, BA

PhD Student

Duke University

Abraham Waldman, PhD

Postdoctoral Fellow

Stanford University 
Micaiah Ward, BSc

PhD Candidate in Cellular and Molecular Biology

Florida State University

Omar Wasow, PhD

Assistant Professor of Politics

Princeton University

Ryan Watson, PhD

Assistant Professor of Human Development and Family Studies

University of Connecticut

Bradley M. Weisz, PhD

Assistant Professor of Psychology

California State University, Long Beach

Brenton M. Wiernik, $\mathrm{PhD}$

Assistant Professor of Psychology

University of South Florida

Katie Wilkinson, $\mathrm{PhD}$

Associate Professor of Biological Sciences

San Jose State University

Wendy M. Williams, PhD

Professor of Human Development

Cornell University

Bianca D.M Wilson, PhD

Rabbi Barbara Zacky Senior Scholar of Public Policy

Williams Institute, UCLA School of Law

Joseph P. Wilson, PhD

Senior Education Consultant

American Institutes for Research

Matthew Wipperman, $\mathrm{PhD}$

Research Scholar

Memorial Sloan Kettering Cancer Center

Daniela Witten, $\mathrm{PhD}$

Professor of Statistics and Biostatistics

University of Washington 
Lisa $\mathrm{Xu}$

$\mathrm{PhD}$ Candidate

Harvard University

Jeffrey M Yau, PhD

Assistant Professor of Neuroscience

Baylor College of Medicine

Jeremy B. Yoder, PhD

Assistant Professor of Biology

California State University Northridge

Joshua Zosky, BA

Graduate Student

University of Nebraska-Lincoln

Arnold M. Zwicky, PhD

Distinguished University Professor of Linguistics, Emeritus

The Ohio State University 